\title{
The Community Law Compliance with Marriage Age Limitation Provisions
}

\author{
Abdul Wahab*) and Akhmad Khisni**) \\ *) Ministry of Religion Office of Demak Regency, E-mail: alex wahab@yahoo.com \\ $\left.{ }^{* *}\right)$ Faculty of Law, Universitas Islam Sultan Agung (UNISSULA) Semarang
}

\begin{abstract}
.
The objectives of this research are to find out and analyze the community's legal compliance with Act No. 16 of 2019 concerning the Provisions on the Marriage Age Limit and the inhibiting factors for the implementation of Act No. 16 of 2019 concerning the Provisions on the Marriage Age Limit as well as efforts to overcome obstacles to the implementation of Act. This study uses a sociological juridical approach, with descriptive research specifications. The results of this study are Community Legal Compliance with Act No. 16 of 2019 concerning Provisions on Marriage Age Limits, where it is known that public legal awareness of underage marriage is relatively low, where some of the people who already know these rules still register their children's marriages. Inhibiting factors include: First, there are still people who do not know the contents of the policy. Second, there are still people who do not know the benefits. The third is the lack of success of the goal of the law in question is to reduce the rate of marriage at a young age. Efforts to overcome for the prospective bride and groom who have not reached the age of 19 years, their parents/guardians are requested to apply for a Marriage Dispensation to the Religious Court in the area where they live. Keywords: Age; Limitation; Law; Marriage; Obedience.
\end{abstract}

\section{Introduction}

Setting a different minimum age for marriage between men and women not only creates discrimination in the context of implementing the right to form a family as guaranteed in Article 28B paragraph (1) of the 1945 Constitution, but also creates discrimination against the protection and fulfillment of children's rights as guaranteed in Article 28B paragraph (2) of the 1945 Constitution. In this case, when the minimum age of marriage for women is lower than for men, legally women can form a family faster.

The legal norms resulting from the draft of the Constitutional Court Judges according to Article 47 of Act No. 24 of 2003 as amended by Act No. 8 of 2011 concerning the Constitutional Court shall take effect as of the completion of the pronouncement of the Constitutional Court judges. The Court is final and binding, among others, aims to provide certainty The law of certainty is intended, so that with the decision of the Constitutional Court judge on February 13, 2012 automatically or automatically becomes the legal norm for the Indonesian nation, so that judges both within the Islamic Courts and generally the environmental Courts often examine and adjudicate the actions of civil judges related to with the 
rights of women and children must use it as a guide in deciding cases related to children's civil rights claims, including the civil rights of children out of wedlock. ${ }^{1}$

One of the basic human needs is the distribution of biological wants. In order to properly distribute biological desires and feel honorable, one must follow the established religious rules. Because, apart from being social creatures, humans are also religious creatures. ${ }^{2}$

Marriage is a very important legal event in human life with various legal consequences. ${ }^{3}$ Therefore the law that regulates marriage in detail. Act No. 1 of 1974 concerning Marriage states that marriage is an inner and outer bond between a man and a woman as husband and wife, with the aim of forming a happy and lasting household (family) based on the One Godhead, furthermore Article 2 paragraph (1) states that marriage is legal if it is carried out according to the law of each religion and belief, and in paragraph (2) it is stated that marriages are recorded in accordance with the applicable laws and regulations. ${ }^{4}$

Marriage is the initial stage of community formation, from being a small form of society called a household. Allah has created men and women to be able to relate to each other, love each other, love each other, produce offspring and live side by side in peace and prosperity in accordance with Allah's commands and the hadith of the Prophet Muhammad. ${ }^{5}$ As mentioned in the Qur'an surah Ar Ruum Verse 21.

The debate about the age limit of children where a person is considered an adult in the context of marriage is related to readiness and maturity not only physically, but also psychologically, economically, socially, mentally, religiously, and culturally. This is because marriage at an early age often poses various risks, both biological risks, such as damage to reproductive organs, as well as psychological risks.

This confusion in determining the limits of normative maturity occurs because there are different legal perspectives on the problems that develop in society at all social levels ${ }^{6}$. According to Act No. 23 of 2002 concerning Child Protection, the category of children is people who are still under the age of 18 years, while in Act No. 26 of 2000 on the Human Rights Court formulated the category of adults aged 18 years, Act No. 30 of 2004 concerning the Notary

\footnotetext{
${ }^{1}$ Rofi'atun, Akhmad Khisni and Rozihan, "Civil Rights Of Children Outside Married Due Isbat Nikah Of Polygamy (Analysis of Islamic Court of Rembang Decision No. 99 / Pdt.G / 2018 / PA.Rbg.)", Jurnal Daulat Hukum Volume 2 (4), p. 617-618 http://jurnal.unissula.ac.id/index.php/RH/article/view/8377/3911

${ }^{2}$ Ahmad Mustarsidin and Akhmad Khisni, "Pregnancy Married in The Perspective of Four Madzhab and Compilation of Islamic Law (KHI)", Jurnal Daulat Hukum Volume 1 (3), p. 699 http://jurnal.unissula.ac.id/index.php/RH/article/view/3370/2495

${ }^{3}$ Achmad Budi Waskito, "Implementation of Itsbat Nikah as A Way To Get The Legal Power Which is not Recorded", Jurnal Daulat Hukum Volume 1 (2), p. 551 http://jurnal.unissula.ac.id/index.php/RH/article/view/3325/2456 ${ }^{4}$ Munir Fuady, (2014), Konsep Hukum Perdata, Jakarta: Raja Grafindo Persada, p. 10.

${ }^{5}$ Rahman, (1996), Karakteristik Hukum Islam dan Perkawinan, Jakarta: Raja Grafindo Persada, p. 203.

${ }^{6}$ Chuasanga A., Ong Argo Victoria, Legal Principles Under Criminal Law in Indonesia and Thailand, $\begin{array}{llllll}\text { Jurnal Daulat Hukum, Vol } & \text { 2, } & \text { No } & 1 & \text { (2019) }\end{array}$ http://jurnal.unissula.ac.id/index.php/RH/article/view/4218
} 
Position, it is stated that the adult requirement is 18 years old (or has been / has been married). ${ }^{7}$

Increasing the age limit higher than 16 (sixteen) years for women to marry will result in lower birth rates and reduce the risk of maternal and child mortality. In addition, it can also fulfill children's rights so as to optimize children's growth and development including parental assistance and provide children's access to education as high as possible.

The purpose of this study is: To find out and analyze the community's legal compliance with Act No. 16 of 2019 concerning the Provisions on Marriage Age Limits. To find out and analyze the inhibiting factors for the implementation of Act No. 16 of 2019 concerning the Provisions on the Marriage Age Limit. To find out and analyze efforts to overcome obstacles to the implementation of Act No. 16 of 2019 concerning Provisions on the Marriage Age Limit.

\section{Research Methods}

The approach method used by the author in this study is a sociological juridical approach. The sociological juridical approach is an approach that emphasizes the science of law and seeks to examine the legal rules that apply in society. ${ }^{8}$ The type of research used by the author in this research is descriptive research. The sources and types of data in this study are secondary data. The method of data collection was obtained from literature study. Data analyzed qualitatively.

\section{Result and Discussion}

\subsection{Community Legal Compliance with Act No. 16 of 2019 concerning Provisions on Marriage Age Limits}

Marriage is an inner bond between a man and a woman as husband and wife with the aim of forming a happy and lasting family (household) based on God. ${ }^{9}$ The age limit for marriage as in Article 7 paragraph 1 of Act No. 1 of 1974 states, the age limit for marriage is 19 (nineteen) years for men and 16 (sixteen) years for women. ${ }^{10}$ For men under 21 years old and over 19 years old, parental consent must be obtained, while under the age of 19 years it is done with a religious court dispensation permit, for women under 21 years old is the property of parents' permission, under 16 years old is court permission. ${ }^{11}$ After the enactment of Act

\footnotetext{
${ }^{7}$ Andi Sjamsu Alam, (2011), "Usia Perkawinan dalam Perspektif Filsafat Hukum dan Kontribusinya Bagi Pengembangan Hukum Perkawinan Indonesia, Disertasi, Jogjakarta: Universitas Gajah Mada, p. 3.

${ }^{8}$ Roni Hanitijo Soemitro, 1988, Metode Penelitian Hukum dan Jurimetri, Jakarta: Ghalia Indonesia, p.106

${ }^{9}$ Hilman Kusuma, (1990), Hukum Perkawinan Indonesia, Jakarta: Mandar Maju, p. 170.

${ }^{10}$ Moh. Idris Ramulyo, (2004), Hukum Perkawinan Islam Suatu Analisis dari Undang-Undang Nomor

1 Tahun 1974 dan Kompilasi Hukum Islam (KHI), Jakarta: Bumi Aksara, p. 1

${ }^{11}$ Samsul Arifin, Akhmad Khisni, and Munsharif Abdul Chalim, "The Limit Of Age Of Marriage Is Related To The Certification Of Marriage (Study Of Early Marriage Reality In Jepara Regency)", $\begin{array}{llllll}\text { Jurnal Daulat Hukum } & \text { (2), } & \text { p. } & 291\end{array}$ http://jurnal.unissula.ac.id/index.php/RH/article/view/10084/4157
} 
No. 16 of 2019 that the minimum age for both men and women is at least 19 years, so it does not conflict with Act No. 23 of 2002 concerning Child Protection. ${ }^{12}$

Legal obedience according to Beni Ahmad Saebeni means a sincere state that arises from the conscience in recognizing and practicing something in accordance with the guidance contained in it, which arises from the deepest conscience and soul of humans as individuals or society to carry out the messages contained in the law". 13

According to Soerjono Soekanto, there are four elements of legal awareness, namely: 14

- Knowledge of law,

- Knowledge of legal content,

- Legal attitude,

- Legal Behavior Patterns.

In Indonesia, the issue of legal awareness has a very important place in legal politics in particular, as well as in development in general, which is a planned change. Understanding legal awareness actually revolves around citizens who are the determining factor for the validity of a law. At first the problem of legal awareness arose in the process of applying a written positive law. However, within the framework of the process, a problem arises, resulting in a discrepancy between the basis of legal validity, namely the social control of the authorities and the legal awareness of the community and the facts that positive law is obeyed or not. 15

The age limit for marriage is explained in Article 7 paragraph (1) of the Law of the Republic of Indonesia No. 16 of 2019 concerning Amendments to Act No. 1 of 1974 concerning Marriage which reads as follows "marriage is only permitted if a man and a woman have reached the age of 19 (nineteen) years".

The legal behavior of the community is an indication that reflects a society that is aware of the law or not aware of the law. At this stage it can be assessed by looking at the behavior of the community whether the legal behavior of the community is in accordance with legal rules or not. But on the other hand, if they are indifferent to the law because they are not aware of the law, the purpose of the law, it can be said that the community is not aware of the law. ${ }^{16}$

Legal counseling must be given by the legal officers to the community directly, by providing special education or education so that it can be conveyed properly to the community. Legal counseling to the community can be used as a solid and strong foundation for the community to avoid the behavior of irresponsible legal officers. Thus the community is protected from the interests of law enforcement (irresponsible) who use the law as a way to scare the public. ${ }^{17}$

\footnotetext{
12Sudarmo, (2005), Hukum Perkawinan, Jakarta: Rineka Cipta, p. 7

13 Saebeni, Ahmad Beni, (2006), Sosiologi Hukum, Bandung: Pustaka Setia, p. 197

14 Soekanto, Soerjono, (2017). PokokPokok Sosiologi Hukum. Jakarta: Rajawali, p. 159

15 Ahmad Tholabi Kharlie, 2008, Kesadaran Hukum Masyarakat Lebak, Banten (studi atas implementasi UU No. 1 Tahun 1974 Tentang Perkawinan). Jurnal Al-Qalam. Vol 25.

16 Sudarsono. (2010). Hukum Perkawinan Nasional. Jakarta: Rineka Cipta. Widiasworo, Erwin. 2018. Mahir Penelitian Pendidikan Modern. Yogyakarta: Araska, p. 66

17 Soekanto, Soerjono. (1989). "Suatu Tinjauan Sosiologi Hukum Terhadap Masalah-Masalah Sosial”. Bandung: IKAPI, p. 199
} 
The public's legal awareness of child marriage can arise due to knowledge of the surroundings and the environment in which they live. For example, in urban communities, most urban communities prefer to receive higher education in order to achieve a better future. Because the surrounding environment is very influential on the progress of one's thinking. In general, the more advanced the society, the more legal knowledge it understands.

The community's legal compliance with Act No. 16 of 2019 concerning Provisions on the Marriage Age Limit is the public's legal awareness of underage marriage is relatively low, where some people already know the rules relating to marriage, but they still marry off their children who have clearly violated these rules. In this case, it is the appropriate age to carry out a marriage.

\subsection{Factors Inhibiting the Implementation of Act No. 16 of 2019 concerning Provisions on the Marriage Age Limit}

Marriage is everyone's dream in the world. Together and happy life is the hope in marriage. ${ }^{18}$ The science of Fiqh of marriage according to the terms used the word "Nikaaha" and the word "Ziwaaj". According to the true meaning of marriage is "Dham" means to squeeze, destroy or assemble while the meaning is "wathaa" which means "Agreement" means to hold the marriage. ${ }^{19}$

There are three main actions that can be taken to increase and foster legal awareness and legal compliance:

- Repressive measures, this must be drastic, firm. Law enforcement officers in carrying out law enforcement must be more firm and consistent. Supervision of law enforcement officers should be further increased or tightened. The more lax implementation of law enforcement will lead to a decline in legal awareness. Law enforcement officers must not discriminate between groups.

- Preventive action is an effort to prevent violations of the law or the decline in legal awareness. By intensifying legal threats against certain legal violations, it is hoped that certain legal violations can be prevented. Likewise, legal compliance or compliance with citizens needs to be closely monitored.

- Persuasive action, namely encouraging, spurring. Legal awareness is closely related to law, while law is a product of culture. Culture includes a system of goals and legal values are a reflection of the values contained in society. Instilling legal awareness means instilling cultural values.

Several experts and the results of this study indicate the factors that occur in early marriage in the community are as follows: ${ }^{20}$

A. Economically, marriage at a young age occurs because the family's situation is on the line of possibility, so to lighten the burden on parents, their daughter is married to someone who is considered capable.

18 Siti Muzazanah, Akhmad Khisni and Rozihan, 2019, Judge Consideration of Religious Court Of Blora on Application of Married Dispensation, dalam Jurnal Daulat Hukum Volume 2 (4), Published Master Of Law, Faculty of Law Unissula p. 551 http://jurnal.unissula.ac.id/index.php/RH/article/view/8356/3898

${ }^{19}$ Sayyid Sabiq, (2011), Fikih Sunnah 3, Jakarta: Cakrawala Publishing, p. 197

20 Endraswari, (1999), Fenomena Kawin Muda dan Aborsi: Gambaran Kasus, dalam Syafiq Hasyim (ed.) Menakar "Harga" Perempuan, Bandung: Mizan, p. 131-132. 
B. Education, the low level of education and knowledge of parents, children and the community causes a tendency to marry underage children.

C. Parents, parents are worried that they will be disgraced because their daughter is dating a man who is very clingy so they immediately marry off their child.

D. The mass media, the incessant exposition of sex in the mass media has caused modern youth to become increasingly permissive of sex.

E. Traditionally, early marriage occurs because parents are embarrassed, worried, and even afraid that their child is said to be an old virgin so that they are immediately married.

The enactment of Act No. 1 of 1974 concerning Marriage, which was followed by the issuance of the Presidential Instruction of the Republic of Indonesia Number 1 of 1991 on June 10, 1991 concerning the dissemination of the Indonesian Islamic Law Compilation to all Heads of Religious Courts and Heads of Religious High Courts, has given a new color to Islamic legal thought in Indonesia. Indonesia. One of the goals of the KHI itself is to overcome the diversity of decisions of the Religious Courts in Indonesia, which so far are still guided by classical Fiqh books and provide new nuances in legal thought in Indonesia that have not previously been discussed or have not been explicitly confirmed. One of the provisions of the previous article received a strong reaction from Muslims as stated in Article 7 paragraph (1) regarding the minimum age limit for marriage. Article 7 paragraph (1) of the Marriage Law states that marriage is only permitted if the man has reached the age of 19 (nineteen) years and the woman has reached the age of 16 (sixteen) years. ${ }^{21}$

The Obstacles to the Implementation of Act No. 16 of 2019 concerning Provisions on the Marriage Age Limit are the first is seen from the content of the policy where there are still people who do not know the contents of the policy Act No. 16 of 2019. Second, there are still people who do not know the benefits of Act No. 16 of 2019. The third is the Degree of Change according to the purpose of Act No. 16 of 2019 is to reduce the rate of marriage at a young age.

\subsection{Efforts to Overcome Barriers to the Implementation of Act No. 16 of 2019 concerning Provisions on Marriage Age Limits}

In essence, everything in this world God created in pairs, as well as humans. God created humans in pairs so that humans can have offspring through marriage. Because marriage according to its original meaning is sexual intercourse but according to majazi (methaporic) or legal meaning it is a contract (agreement) that makes sexual relations lawful as a husband and wife or a man and a woman. ${ }^{22}$ In a broader sense, marriage is regulated in Act No. 1 of 1974 concerning Marriage, in this Law it is stated that marriage is an inner and outer bond between a man and a woman as husband and wife with the aim of forming a happy and eternal family (household) based on God Almighty. ${ }^{23}$ Meanwhile, the Compilation of Islamic Law

\footnotetext{
21 Sutan Marajo Nasaruddin Latif, (2001), Problematika Seputar Keluarga Dan Rumah Tangga, Bandung: Pustaka Hidayah, p. 23.

22 Fauziatu Shufiyah, 2018, Pernikahan Dini Menurut Hadits dan Dampaknya. Jurnal Living Hadits, Volume 3, No. 1, p.49

23 Team Redaksi Nuansa Aulia, (2020), Kompilasi Hukum Islam, Bandung: Nuansa Auli, p. 74
} 
in Indonesia defines marriage according to Islam as a strong contract or miitsaqan ghalizhan to obey Allah's commands and carry it out as worship.

Determining the age limit for marriage is very important, because a marriage requires a biological relationship that results in health. As in the explanation of the Marriage Law, it is stated that the prospective husband and wife must have matured in mind and body to be able to carry out a marriage so that they can realize a good marriage without ending in divorce and get good and healthy offspring. For this reason, marriages between prospective husbands and wives who are still under age must be prevented. ${ }^{24}$

Regarding the change in the age limit for marriage, if you look at the age for someone who is suitable for marriage, according to Bogue, there are 4 classifications of age patterns of marriage, namely: 1). Child marriage for marriages under 18 years old; 2). Early marriage for those aged 18-19 years; 3). Marriage at maturity (marriage at maturity) for marriage aged 20-21 years; and 4). Late marriage for those aged 22 years and over. ${ }^{25}$

Efforts to Overcome Barriers to the Implementation of Act No. 16 of 2019 concerning Provisions on Marriage Age Limits is for the prospective bride and groom who are to be married have not yet reached the age of 19 years, the parents/guardians of the male and/or the parents/guardians of the female may request a dispensation from the Court on the grounds of urgency with sufficient supporting evidence. For Muslim communities who experience conditions like the above, they can submit a voluntary case (application) for Marriage Dispensation to the Religious Court in the area where they live or to the Religious Court where the marriage will be carried out.

\section{Clossing}

Community legal compliance with Act No. 16 of 2019 concerning Age Limit Provisions is still relatively low, where some of the people who already know these rules still register their children's marriages who do not meet the age limit requirements. The inhibiting factor is that there are still people who do not know the contents of the policy of the Act, then there are still people who do not know the benefits of the new Law and the lack of success of the purpose of the Act in question, namely to reduce the rate of marriage at a young age. Efforts to overcome this are for the prospective bride and groom who have not reached the age of 19 years, then the parents/guardians are asked to apply for a Marriage Dispensation to the Religious Court in the area where they live.

\section{References}

\section{Journals:}

\footnotetext{
24 Heriawanto, B. K. "Interfaith Marriages Based On Positive Law In Indonesia And Private International Law Principles”, Unifikasi: Jurnal Ilmu Hukum, 6 (1), 6 (1).

${ }^{25}$ Salma, S, "Pernikahan Dini Ditinjau Dari Sudut Pandang Sosial Dan Pendidikan”, Jurnal Ilmu Dan Teknik Dakwah, 4 (7).
} 
[1] Achmad Budi Waskito, "Implementation of Itsbat Nikah as A Way To Get The Legal Power Which is not Recorded", Jurnal Daulat Hukum Volume 1 (2), p. 551 http://jurnal.unissula.ac.id/index.php/RH/article/view/3325/2456

[2] Ahmad Mustarsidin and Akhmad Khisni, "Pregnancy Married in The Perspective of Four Madzhab and Compilation of Islamic Law (KHI)", Jurnal $\begin{array}{llllll}\text { Daulat Hukum } & \text { Volume } & 1 & \text { (3), } & \text { p. } & 699\end{array}$ http://jurnal.unissula.ac.id/index.php/RH/article/view/3370/2495

[3] Ahmad Tholabi Kharlie, "Kesadaran Hukum Masyarakat Lebak, Banten (studi atas implementasi UU No. 1 Tahun 1974 Tentang Perkawinan)”, Jurnal AlQalam. Vol 25.

[4] Chuasanga A., Ong Argo Victoria, "Legal Principles Under Criminal Law in Indonesia and Thailand", Jurnal Daulat Hukum, Vol 2, No 1 (2019) http://jurnal.unissula.ac.id/index.php/RH/article/view/4218

[5] Fauziatu Shufiyah, "Pernikahan Dini Menurut Hadits dan Dampaknya", Jurnal Living Hadits, Volume 3, No. 1

[6] Heriawanto, B. K., "Interfaith Marriages Based On Positive Law In Indonesia And Private International Law Principles", Unifikasi: Jurnal Ilmu Hukum, 6 (1).

[7] Rofi'atun, Akhmad Khisni and Rozihan, "Civil Rights Of Children Outside Married Due Isbat Nikah Of Polygamy (Analysis of Islamic Court of Rembang Decision No. 99 / Pdt.G / 2018 / PA.Rbg.)", Jurnal Daulat Hukum Volume 2 (4), p. 617-618 http://jurnal.unissula.ac.id/index.php/RH/article/view/8377/3911

[8] Salma, S, "Pernikahan Dini Ditinjau Dari Sudut Pandang Sosial Dan Pendidikan", Jurnal Ilmu Dan Teknik Dakwah, 4 (7).

[9] Samsul Arifin, Akhmad Khisni, and Munsharif Abdul Chalim, "The Limit Of Age Of Marriage Is Related To The Certification Of Marriage (Study Of Early Marriage Reality In Jepara Regency)", Jurnal Daulat Hukum Volume 3 (2), p. 291 http://jurnal.unissula.ac.id/index.php/RH/article/view/10084/4157

[10] Siti Muzazanah, Akhmad Khisni and Rozihan, "Judge Consideration of Religious Court Of Blora on Application of Married Dispensation", Jurnal Daulat Hukum Volume 2 (4), p. 551 http://jurnal.unissula.ac.id/index.php/RH/article/view/8356/3898

\section{Books:}

[1] Andi Sjamsu Alam, (2011), "Usia Perkawinan dalam Perspektif Filsafat Hukum dan Kontribusinya Bagi Pengembangan Hukum Perkawinan Indonesia, Disertasi, Jogjakarta: Universitas Gajah Mada

[2] Endraswari, (1999), Fenomena Kawin Muda dan Aborsi: Gambaran Kasus, dalam Syafiq Hasyim (ed.) Menakar "Harga" Perempuan, Bandung: Mizan

[3] Hilman Kusuma, (1990), Hukum Perkawinan Indonesia, Jakarta: Mandar Maju

[4] Moh. Idris Ramulyo, (2004), Hukum Perkawinan Islam Suatu Analisis dari Undang-Undang Nomor 1 Tahun 1974 dan Kompilasi Hukum Islam (KHI), Jakarta: Bumi Aksara

[5] Munir Fuady, (2014), Konsep Hukum Perdata, Jakarta: Raja Grafindo Persada

[6] Rahman, (1996), Karakteristik Hukum Islam dan Perkawinan, Jakarta: Raja Grafindo Persada 
[7] Roni Hanitijo Soemitro, 1988, Metode Penelitian Hukum dan Jurimetri, Jakarta: Ghalia Indonesia

[8] Saebeni, Ahmad Beni, 2006, Sosiologi Hukum, Bandung: Pustaka Setia

[9] Sayyid Sabiq, 2011, Fikih Sunnah 3, Jakarta: Cakrawala Publishing

[10] Soekanto, Soerjono, 2017, PokokPokok Sosiologi Hukum. Jakarta: Rajawali

[11] Soekanto, Soerjono, 1989, "Suatu Tinjauan Sosiologi Hukum Terhadap Masalah- Masalah Sosial". Bandung: IKAPI.

[12] Sudarmo, 2005, Hukum Perkawinan, Jakarta: Rineka Cipta

[13] Sudarsono, 2010, Hukum Perkawinan Nasional. Jakarta: Rineka Cipta. Widiasworo, Erwin, 2018, Mahir Penelitian Pendidikan Modern. Yogyakarta: Araska

[14] Sutan Marajo Nasaruddin Latif, 2001, Problematika Seputar Keluarga Dan Rumah Tangga, Bandung: Pustaka Hidayah

[15] Team Redaksi Nuansa Aulia, 2020, Kompilasi Hukum Islam, Bandung: Nuansa Aulia 